\title{
PARENTING EDUCATION GUNA MENINGKATKAN PARENTING SELF-EFFICACY PADA ORANG TUA DARIANAK DENGAN GANGGUAN AUTISME
}

\author{
Ni Luh Drajati Ekaningtyas \\ Program Studi PG-PAUD STAHN Gde Pudja Mataram \\ drajatieka@gmail.com
}

\begin{abstract}
Abstrak
Orang tua dari anak dengan gangguan autisme menghadapi banyak tantangan dan beban psikologis yang dapat menyebabkan stres dan depresi sehingga mempengaruhi kualitas pengasuhan yang diberikan. Parenting self-efficacy yang tinggi dapat membantu mengatasi stressor yang muncul terkait pengasuhan. Parenting education dalam bentuk psikoedukasi dapat digunakan untuk membentuk dan meningkatkan parenting self-efficacy karena dapat membentuk atau mengubah persepsidan meningkatkan aspek kognitif atau pemahaman orang tua mengenai strategi penanganan anak dengan gangguan autisme.
\end{abstract}

Kata Kunci: Parenting education, parenting self-efficacy, pengasuhan anak autis

\begin{abstract}
Parents of children with autism disorder faces many challenges and psychological burdens which can cause stress and depression that can affect parenting quality given to the children. Hence, the ideal amount of parenting self-efficacy is needed in order to overcome stressors related to parenting. Parenting education in a form of psychoeducation can be used to create and improve parenting self-efficacy by establishing/intensifying perceptions and increasing the parent's cognitive or understanding regarding parenting strategy of children with autism disorder.
\end{abstract}

Keywords: Parenting education, parenting self-efficacy, children with autism

\section{PENDAHULUAN}

Seperti halnya anak normal, anak dengan kebutuhan khusus juga merupakan bagian dari hidup kita sehingga tidak boleh kita abaikan. Selain memperhatikan keberadaannya, kita juga harus membantu mengatasiketerbatasan mereka sehingga mereka akan mampu menyelesaikan tugas-tugas perkembangan sepanjang usia mereka. Salah satu gangguan pada anak usia dini yang menjadi perhatian orang tua dan pendidik PAUD adalah gangguan autisme. 
Monks dkk. (2002) menyatakan bahwa autisme berasal dari kata autos yang berarti aku. Berk (2012) menggambarkan autisme dengan istilah absorbed in the self atau keasyikan dalam dirinya sendiri. Sementara Wall (2004) mengartikan autisme sebagai aloof atau withdrawn, yang menggambarkan bahwa anakanak dengan gangguan autisme tidak tertarik dengan dunia disekelilingnya. Secara sederhana, autisme dapat diartikan sebagai sikap anak yang cenderung suka menyendiri karena terlalu asyik dengan dunianyasendiri.

Gangguan autisme muncul sebelum usia 3 tahun tanpa memandang lapisan sosial ekonomi, tingkat pendidikan orang tua, ras, etnik, maupun agama. Anak yang mengalami gangguan autisme sejak dilahirkan disebut dengan autisme klasik, sementara anak dengan gangguan autisme yang munculsetelahberusia 1,5 hingga 2 tahun disebut dengan autisme regresi. Menurut Maulana (2007) autisme terjadi pada 5 dari 10.000 kelahiran dengan jumlahpenderita laki-laki empat kali lebih besar dibandingkan dengan penderita perempuan. Namun jika perempuan yang menderitanya, penderitanya akan lebih parah dibandingkan denganlaki-laki.

Bashir, Bashir, Lone, dan Ahmad (2014) menyatakan bahwa autisme dianggap sebagai gangguan yang berat karena berdampak seumur hidup bagi individu dan keluarganya. Orang tua dari anak dengan gangguan autisme dihadapkan pada kesulitan yang berat untuk menghadapi tantangan perilaku, mengajarkan berkomunikasi, mengajarkan keterampilan hidup dasar, menjaga anak dari bahaya, dan mempersiapkan anak mereka untuk kehidupan di usia dewasa. Tantangan lain yang harus dihadapi orang tua dengan anak autis terkait pengasuhan antara lain munculnya permasalahan dengan saudara kandung yang normal yang seringkali merasa malu, kurang diperhatikan dan diperlakukan tidak adilkarena orang tua yang lebih fokus pada anak yang memiliki gangguan autis. Tantangan berikutnya yang harus dihadapi orang tua dari anak dengan gangguan autisme terkait dengan finansial, dimana asuransi biasanya tidak menanggung biaya mahalyang dibutuhkan untuk pengobatan dan terapi. Kehadiran anak dengan gangguan autisme juga dapat menjadi pemicu permasalahan pernikahan, terutama kerika tidak terjalin kerjasama yang baik terkait pembagian peran antar orang tua.

Beban psikologis yang dirasakan orang tua dari anak dengan gangguan autis akan berdampak pada masalah psikososial keluarga, yang pada akhirnya dapat menyebabkan kecemasan dan menjadi sumber stres dalam keluarga. Penelitian yang dilakukan Koydemir \& Tosun (2009) menggambarkan bahwa stress tinggi adalah dampak yang dirasakan oleh orang tua yang memilikianak autis. Stres ini dipicu oleh rasa lelah yang tinggi, rasa khawatir akan masa depan dan kemandirian anak, karir yang terhambat, masalah finansial yang belum tercukupi karena kebutuhan terapi dan pengobatan anak dengan gangguan autis yang cukup mahal, dan pandangan orang lain tentang kondisi anak.

Stres pada orang tua dari anak dengan gangguan autis bukan hal yang dapat diabaikan karena dapat mempengaruhi perilaku orang tua dalam memberikan pengasuhan. Batool \& Khurshid (2015) menyatakan bahwa terdapat dua faktor yang secara signifikan mempengaruhi 
stres pada orang tua dengan anak autis, yaitu derajat atau tingkat keparahan autisme anak dan parenting self-efficacy atau keyakinan orang tua dalampengasuhananak. Coleman \& Gillberg (2011) mendefinisikan parenting self-efficacy (PSE) sebagai penilaian orang tua terhadap kompetensi mereka dalam menjalankan peran mereka sebagai orang tua atau persepsi orang tua tentang kemampuan mereka untuk secara positif mempengaruhi perilaku dan perkembangan anak-anak mereka. Orang tua yang memiliki keyakinan yang kuat akan kemampuannya dalam pengasuhan memiliki emotional well-being yang lebih positif, kelekatan yang lebih baik dengan anaknya, dan memiliki peran yang lebih baik sebagai orang tua. Oleh karena itu, PSE harus dimiliki oleh setiap orang tua dengan anak autis yang menghadapi banyak tantangan dalam proses pengasuhan karena PSE merupakan faktor utama dalam menentukan perilaku apa yang akan dilakukan orang tua dan upaya mengatasi tantangan serta persistensi yang akan ditunjukkan orang tua saat menghadapi kesulitan.

Hasil penelitian yang dilakukan Salas, dkk. (2017) menggambarkan bahwa orang tua dengan anak autis mengalami banyak kesulitan setiap harinya dan strategi koping adalah salah satu variabel yang dapat digunakan untuk menghindarkan diri mereka dari gangguan emosional. Self-efficacy berkorelasi positif dengan strategi koping fungsional (problem solving dan restrukturasi kognitif), dan berkorelasi negatif dengan strategi coping disfungsional (self-criticism, angan-angan, dan penarikan sosial). Dengan kata lain, orang tua dengan self-efficacy yang tinggi dalam hal pengasuhan anak akan cenderung menggunakan strategi koping fungsional sehingga dapat membantunya dalam menghadapi pemicu stres.

Salah satu upaya yang dapat dilakukan untuk mengurangi dampak psikososial yang dirasakan orang tua dari anak dengan gangguan autis adalah dengan memberikan parenting education melalui psikoedukasikepada orang tua. Psikoedukasi dapat dilakukan pada individu, keluarga, dan kelompok yang fokus untuk mendidik pesertanya terkait tantangan signifikan dalam hidup, membantu partisipan mengembangkan sumber-sumberdukungan dan dukungan sosial dalam menghadapi tantangan dan mengembangkan keterampilan koping (Walsh, 2010). Penelitian Stafford, dkk. (2017) menyatakan bahwa psikoedukasi dapat meningkatkan parenting efficacypada orang tua yang mengidap kanker dan memiliki anak yang masih kecil.

Berdasarkan penjabaran diatas, terlihat bahwa parenting education dapat dijadikan sebagai salah satu metode untuk meningkatkan parenting self-efficacy pada orang tua dari anak dengan gangguan autisme sebagai upaya untuk mencapai emotional well-being yang lebih positif, kelekatan yang lebih baik dengan anaknya, dan menjalankan peran yang lebih baik sebagai orangtua.

\section{PEMBAHASAN}

\subsection{Gangguan Autisme pada Anak Usia Dini}

Autisme berasal dari kata autos yang berarti aku (Monks, dkk., 2002). Autisme 
didefinisikan sebagai keasyikan dalam dirinya sendiri atau absorbed in the self (Berk, 2012). Wall (2004) mengistilahkan autisme sebagai aloof atau withdrawn yang mengandung makna bahwa anak dengan gangguan autisme tidak tertarik dengan dunia sekelilingnya. Tilton (2004) menyatakan bahwa pemberian nama autisme didasarkan pada keyakinan akan "keasyikan yang berlebihan dalamdirinya sendiri". Mualana (2007) menyatakan bahwa secara sederhana autisme dapat diartikan sebagai sikap anak yang cenderung suka menyendiri karena terlalu asyik dengan dunianya sendiri. Dengan kata lain, anak dengan gangguan autisme adalah anak yang sibuk dengan urusannya sendiri alih-alih bersosialisasi dengan orang lain di sekitarnya.

Gangguan spektrum autisme (Autism Spectrum Disorder) merupakan gangguan perkembangan yang berpotensi mempengaruhi komunikasiverbal, nonverbal, dan interaksi sosial yang pada umumnya terjadi sebelum usia tiga tahun. Istilah spektrum digunakan untuk mendeskripsikan tingkat keparahan autis karena antara satu individu dengan individu yang lain memiliki tingkat keparahan autis yang berbedabeda (Coleman \& Gillberg, 2011). Menurut Yuwono (2009), jika ditinjau dari kemunculan atau kejadiannya, anak dengan gangguan autisme dibagi menjadi dua macam. Pertama, autisme klasik yaitu gangguan autisme yang dialami anak sejak dilahirkan. Kedua, autisme regresiyaitu gangguanautisme yang dialami anak sejak berusia 1,5-2 tahun.
Kosasih (2012) menjabarkan bahwa gangguan autisme pada anak ditandai dengan tiga gangguan utama, yaitu (1) gangguan interaksi sosial, (2) gangguan komunikasi, dan (3) gangguan perilaku. Menurut Kosasih (2012) dari ketiga gangguan tersebut, yang paling penting untuk ditangani terlebih dahulu adalah gangguan interaksi sosial. Jika interaksi sosial pada anak dengan gangguan autisme dapat membaik, maka gangguan komunikasi dan gangguan perilaku dapat membaik pula. Keterhambatan proses perkembangan pada anak dengan gangguan autis dapat mempengaruhi kemandiriannya, dimana $61-73 \%$ anak dengan gangguan autis tidak mampu hidup secara mandiri. Hanya sekitar 5-17\% anak yang berkembang untuk dapat menjalani kehidupan sosial yang normal hingga dapat bekerja (Coleman \& Gillberg, 2011).

Ketiga gangguan utama autisme (gangguan interaksi sosial, gangguan komunikasi, dan gangguan perilaku) saling terkait satu sama lain. Ketika perilaku bermasalah, maka perkembangan aspek interaksi sosial dan komunikasi juga akan mengalami masalah. Sebaliknya, ketika kemampuan komunikasi anak tidak berkembang, maka anak akan mengalami kesulitan dalam mengembangkan perilaku dan interaksi sosial yang bermakna. Begitu pula ketika anak mengalami kesulitan dalam berinteraksi sosial(Yuwono, 2009).

Prasetyono (2008) menjabarkan ciri-ciri gangguan autisme pada anak usia dini sebagai berikut: 
Tabel 1.1

Ciri-ciri Gangguan Autisme pada Anak Usia Dini

\begin{tabular}{|c|c|c|}
\hline No & Aspek Gangguan & Ciri-ciri Gangguan \\
\hline \multirow[t]{7}{*}{1} & \multirow[t]{7}{*}{ Interaksi Sosial } & 1. Cuek terhadap lingkungan. \\
\hline & & $\begin{array}{l}\text { 2. Kontak mata sangat kurang, bahkan tidak mau menatap } \\
\text { mata lawan bicaranya. }\end{array}$ \\
\hline & & 3. Ekspresi muka kurang hidup \\
\hline & & 4. Tidak mau bermain dengan teman sebayanya \\
\hline & & 5. Suka bermain dengan dirinya sendiri \\
\hline & & $\begin{array}{l}\text { 6. Cara bermain kurang variatif, kurang imajinatif, dan } \\
\text { kurang bisa meniru. }\end{array}$ \\
\hline & & $\begin{array}{l}\text { 7. Tidak memiliki empati atau tidak dapat merasakan apa } \\
\text { yang dirasakan orang lain. }\end{array}$ \\
\hline \multirow[t]{5}{*}{2} & \multirow[t]{5}{*}{ Komunikasi } & 1. Terlambat bicara \\
\hline & & $\begin{array}{l}\text { 2. Tidak memiliki usaha untuk mengimbangi komunikasi } \\
\text { dengan cara lain selain bicara }\end{array}$ \\
\hline & & 3. Jika bicara, bicaranya tidak untuk berkomunikasi \\
\hline & & 4. Sering menggunakan bahasa yang aneh dan diulang-ulang \\
\hline & & 5. Tidak dapat memahami pembicaraan orang lain \\
\hline \multirow[t]{6}{*}{3} & \multirow[t]{6}{*}{ Perilaku } & 1. Cuek terhadap lingkungan \\
\hline & & $\begin{array}{l}\text { 2. Perilaku tidak terarah, seperti suka mondar-mandir, lari- } \\
\text { lari, manjat-manjat, berputar-putar, melompat-lompat, } \\
\text { dan lainnya }\end{array}$ \\
\hline & & $\begin{array}{l}\text { 3. Sering kali sangat terpukau pada benda-benda yang } \\
\text { berputar atau benda-benda yang bergerak }\end{array}$ \\
\hline & & 4. Ada gerakan-gerakan aneh yang khas dan diulang-ulang \\
\hline & & 5. Terpaku pada satu kegiatan rutin yang tidak ada gunanya \\
\hline & & $\begin{array}{l}\text { 6. Mempertahankan satu permintaan atau lebih dengan cara } \\
\text { yang khas dan berlebihan }\end{array}$ \\
\hline
\end{tabular}

Pada ummnya gejala autisme pada anak muncul saat mereka berusia 1,5 hingga 2 tahun. Saat itu seharusnya anak berkembang secara normal, tetapi kemudian perkembangannya terhenti dan mereka mengalami kemunduran. Kemunduran tersebut membuat anak mengalami gangguan autisme. Beberapa hal yang diduga menyebabkan autisme pada anak usia dini adalah sebagai berikut:

a. Adanya kelainan pada susunan saraf pusat pada beberapa tempat di dalam otak, berupa pengurangan jumlah sel purkinje di dalam otak yang menyebabkan kurangnya produksi serotonin sehingga proses 
penyaluran informasi antar-otak menjadi kacau. Selain itu, ditemukan kelainan struktur pada pusat emosi di dalam otak sehingga emosi anak yang mengalami gangguan autisme sering terganggu.

b. Adanya gangguan pada metabolisme (sistem pencernaan) yang menyebabkan anak dengan gangguan autisme mengalami kesulitan makan.

c. Anak yang mengalami gangguan autisme pada umunya ditemukan mengalami peradangan usus yang diduga disebabkan oleh virus, seperti virus campak. Banyak orang tua menolak imunisasi MMR (measles, mumps, rubella) karena diduga dapat menyebabkan gangguan autisme pada anak.

d. Faktor genetik merupakan penyebab umum dari gangguan autisme. Ada beberapa gen yang terkait dengan autisme namun gejala autisme hanya bisa muncul bila terjadi kombinasi banyak gen, dan autisme bisa saja tidak terjadi meskipun anak membawa gen autisme.

e. Keracunan logam berat akibat makanan ringan dan mainan anak yang mengandung logam berat diduga menjadi penyebab kerusakan otak pada anak autis karena ditemukan kandungan logam berat dan beracun pada banyak anak dengan gangguan autisme.

Beberapa jenis terapi untuk anak dengan gangguan autisme yang dapat dilakukan oleh orang tua adalah sebagai berikut:

a. Terapi perilaku. Terapi perilaku merupakan terapi yang penting, mudah dilakukan, dan terbukti dapat memberikan hasil yang memuaskan. Terapi ini dilakukan dengan melatih setiap keterampilan yang dimiliki anak dimulai dari respon sederhana seperti kontak mata sampai yang lebih kompleks seperti komunikasi spontan dan interaksi sosial. Terapi perilaku akan memberikan hasil yang lebih baik ketika dipadukan dengan terapi lainnya seperti terapi wicara, terapi okupasi, dan pendidikan khusus.

b. Terapi bermain. Terapi bermain ditujukan untuk mengembangkan kekuatan otot, motorik, meningkatkan ketahanan organ tubuh bagian dalam, mencegah dan memperbaiki sikap tubuh yang kurang baik, melepaskan anak dari energi berlebih yang dapat merugikan diri sendiri, dan untuk melatih anak dalamberinteraksi sosial.

c. Terapi wicara. Terapi ini merupakan suatu keharusan karena semua penyandang autisme memiliki keterlambatan bicara dan kesulitan berbahasa, baik yang bersifat verbal, non-verbal, maupun kombinasi keduanya. Terapi ini dapat dilakukan dengan cara penyusupan bahasa, yaitu meminta anak menyebutkan nama benda yang ada di hadapannya atau yang ditemukannya pada kondisi tertentu.

Ketiga terapi diatas harus dilaksanakan secara terpadu, tidak boleh ada yang diabaikan. Terapi perilaku dapat dilakukan terlebih dahulu kemudian dibarengi dengan terapi bermain dan terapi wicara secara berkesinambungan. Dalam pemberian terapi-terapi ini, orang tua dapat bekerjasama dengan guru PAUD.

\subsection{Parenting Self-efficacy}

Bandura menjelaskan bahwa bagaimana individu bertingkah laku dalam suatu situasi 
bergantung pada resiprokal antara lingkungan dengan kognisi kognitif, terutama faktor kognitif yang berhubungan dengan keyakinan bahwa ia mampu atau tidak mampu melakukan tindakan memuaskan. self-efficacy atau efikasi diri merupakan penilaian diri terkait apakah mampu melakukan tindakan yang baik atau buruk, tepat atau salah, bisa atau tidak bisa mengerjakan sesuai dengan yang dipersyaratkanBandura juga menyatakan bahwa self-efficacy bersifat domain-spesific. (Alwisol, 2009). Perasaan kompeten dalam satu bidang kehidupan seseorang (seperti karir atau pendidikan) mungkin akan berbeda dengan perasaan kompetennya di bidang lain, misalnya mengasuh anak (Delft, 2012).

Coleman \& Gillberg (2011) menyatakan bahwa parenting self- efficacy (PSE) merupakan penilaian orang tua terhadap kompetensi dirinya dalam peran sebagai orang tua atau persepsi orang tua tentang kemampuan mereka untuk secara positif mempengaruhi perilaku dan perkembangan anak-anak mereka. PSE ini merupakan salah satu bagian dari aspek kognitif dalamkompetensi pengasuhan, sehingga berdampak langsung pada perilaku yang ditunjukkan orang tua saat berhubungan dengan anak dan pada tingkat kepuasan orang tua dalam merawat anak. PSE menjadi penting karena merupakan faktor utama dalam menentukan perilaku dan upaya yang akan dilakukan, serta persistensi yang akan ditunjukkan orang tua saat menghadapi kesulitan dalam pengasuhan.

Matthews \& Hamilton (dalam Antawi \& Murdiyani, 2013) menyatakan bahwa hasil studi menunjukkan PSE berkontribusi positif terhadap keterampilan pengasuhan yang adaptif dan berkolerasi negatif dengan tingkat stress pengasuhan dan depresi. PSE memiliki peran penting dalam proses adaptasi individu dalam menjalankan perannya sebagai orang tua. Ibu yang memiliki keyakinan yang kuat mengenai kemampuannya dalammemberikan pengasuhan memiliki emotional well-being yang lebih positif, attachment yang lebih baik dengan anaknya, dan memilikiperan yang lebih baik sebagaiorang tua, serta tidak terlalu banyak mengalami konflik dalam menjalankan peran sebagai orang tua dan memiliki hubungan pernikahan yang lebih baik dibandingkan dengan ibu yang memiliki keyakinan yang lebih lemah mengenai kemampuannya dalam menjalankan peran sebagai orang tua. Dengan kata lain, orang tua dengan PSE yang rendah harus berjuang lebih keras untuk memenuhi tuntutan dalam keluarga sehingga berisiko mengalami stres dan depresi. Oleh karena itu, PSE merupakan aspek penting yang harus dimiliki oleh setiap orang tua dari anak dengan gangguanautisme yang menghadapi banyak tantangan dalam proses pengasuhan.

\subsection{Parenting Education untuk Meningkatkan Parenting Self-efficacy}

Bandura menyatakanbahwa self-efficacy bukan merupakan traitkepribadian, melainkan dikonseptualisasikan sebagai komponen yang dinamis. Self-efficacy dapat diperoleh, diubah, ditingkatkan, atau diturunkan melalui salah satu atau kombinasi empat sumber, yaitu pengalaman menguasai suatuprestasi, pengalaman vikarius atau pengalaman mengamati dan menilai model sosial, persuasi sosial, dan pembangkitan emosi (Alwisol, 2009). Modifikasi PSE dapat 
dilakukan melalui suatu intervensi, salah satunya melalui psikoedukasi.

Psikoedukasi adalah sebuah intervensi yang dapat dilakukan pada individu, keluarga, dan kelompok yang berfokus untuk mendidik pesertanya mengenaitantangan signifikan dalam hidup, membantu partisipan mengembangkan sumber-sumber dukungan dan dukungan sosial dalam menghadapi tantangan, serta mengembangkan keterampilan koping. Koping merupakan berbagai macam strategi yang digunakan oleh seseoranguntuk mengatasisituasi sehari-hari atau situasi yang luar biasa. Strategi koping yang efektif dapat membantu mencapai fungsi keluarga secara adekuat. Dukungan profesional yang tepat dapat membantu orang tua dalam mengurangi stres dan memfasilitasi koping dengan menawarkan informasi, bantuan keuangan, dan dukungan emosional (Walsh, 2010).

Psikoedukasi sebagai parenting education dalam upaya meningkatan parenting selfefficacy pada orang tua dari anak yang memiliki gangguan autisme dapat dilakukan dalambentuk sederhana seperti presentasi atau lekturet. Presentasi atau lekturet merupakan bentuk komunikasi atau penyampaian terstruktur atas apa yang disiapkan dan bersifat satu arah dari pihak penyaji atau penceramah kepada khalayak peserta, yang bertujuan untuk menyampaikan informasi lazimnya berupa pengetahuan, pandangan baru yang penting kepada peserta (Supratiknya, 2011). Melalui psikoedukasi dapat dipresentasikan informasi seputar penanganan anak dengan gangguan autisme dan pentingnya PSE bagi orang tua dari anak dengan gangguan autisme sebagai bentuk parenting education.
Hasil penelitian yang dilakukan oleh Purbasafir, Fasikha, dan Saraswati (2018) menggambarkan bagaimana psikoedukasi menjadi salah satu metode intervensi yang efektif untuk meningkatkan PSE pada ibu dari anak penyandang autis melalui kesiapan kognitif dengan memberikan pemahaman dan informasi baru. Penelitian ini menyimpulkan bahwa psikoedukasi mampu mengubah persepsi dan meningkatkan pemahaman atau kognitif ibu tentang strategi pengasuhan anak dengan autis, sehingga PSE juga meningkat seiring dengan peningkatan pemahaman ibu. Hal ini sejalan dengan hasil penelitian Stafford, dkk. (2017) yang menyatakan bahwa psikoedukasi dapat meningkatkan parenting efficacy pada orang tua yang mengidap kanker dan memiliki anak yang masihkecil.

\section{PENUTUP}

Beban psikologis yang dirasakan orang tua dari anak dengan gangguan autisme dapat menjadi sumber stres dan depresi yang dapat mempengaruhi perilaku orang tua dalam memberikan pengasuhan. Selain tingkat keparahan autis, parenting self-efficacy merupakan faktor yang dapat mempengaruhi stres pada orang tua dengan anak autis secara signifikan. Parenting self-efficacy adalah hal yang penting karena merupakan faktor utama dalam menentukan perilaku apa yang akan dilakukan orang tua dan upaya mengatasi tantangan serta persistensi yang akan ditunjukkan orang tua saat menghadapi kesulitan. Parenting education merupakan salah satu intervensiyang dapat digunakan untuk 
meningkatkan Parenting self-efficacy pada orang tua dari anak dengan gangguan autisme karena cukup efektif dalam membentuk/ mengubah persepsi dan meningkatkan aspek kognitif atau pemahaman orang tua mengenai strategi penanganan anak dengan gangguan autisme.

\section{DAFTAR PUSTAKA}

Alwisol. 2009. Psikologi Kepribadian edisi revisi. Malang: UMM Press.

AntawiD. I., dan Murdiyani, H. 2013. Dinamika Psikologis Pembentukan Parenting Self Efficacy pada Orangtua Penyandang Tuna Rungu yang MemilikiAnak Berpendengaran Normal. Jurnal Psikologi Teori dan Terapan. Indonesia: Universitas Negeri Surabaya.

Bashir, A., Bashir, U., Lone, A., and Ahmad, Z. 2014. Challenges Faced by Familied of Autistic Children. International Journal of Interdisciplinary Research and Innovations. India: Research Publish Journals.

Berk, L. E. 2012. Development Through The Lifespan 5th edition. Yogyakarta: Pustaka Pelajar.

Coleman, M., dan Gillberg, C. 2011. The Autisms. United Kingdom: Oxford University Press.
Delft, S.V. 2012. Relationships Between Parental Self Efficacy, Parenting Training Instruction Practices, and Models of Parent Practicions. Thesis. Kanada: The University of British Columbia.

Kosasih, E. 2012. Cara Bijak Memahami Anak Berkebutuhan Khusus. Bandung: Yrama Widya.

Koydemir, S., and Tosun, U. 2009. Impact of Autistic Children on The Lives of Mothers. Procedia Social and Behavioral Sciences. Amsterdam: Elsevier

Maulana, M. 2007. Anak Autis. Yogyakarta: Katahari.

Monks, F. J., Knoers A. M. P., dan Haditono, S. R. 2002. Psikologi Perkembangan: Pengantar dalam Berbagai Bagiannya. Yogyakarta: GadjahMada UniversityPress.

Purbasafir, T. F., Fasikha, S. S., Saraswati, P. 2018. Psikoedukasi untuk Meningkatkan Parenting Self-efficacy pada Ibu Anak Penyandang Autisme. Jurnal Ilmiah Psikologi Terapan. Malang: Fakultas Psikologi UMM.

Prasetyono, D. S. 2008. Biarkan Anakmu

Bermain: Mengenal Manfaat dan Pengaruh Positif Permainan bagi Perkembangan Psikologi Anak. Yogyakarta: Diva Press. 
Salas, B. L., Rodriguez, V. Y., Urbieta, C. T., and Cuadrado, E. 2017. The Role of Coping Strategies and Self-efficacy as Predictors of Life Satisfaction in a Sample of Parents of Children with Autism Spectrum Disorder. Psicothema. Asturias: University of Oviedo

Stafford, L., Sinclair, M., Turner, J., Newman, L., Wakefield, C., Krishnasamy, M., Schofield, P. Study Protocolfor Enhanching Parenting In Cancer (EPIC): Development and Evaluation of a Brief Psychoeducational Intervention to Support Parents with Cancer Who Have Young Children. Pilot and Feasibility Studies. United Kingdom: BMC.

Supratiknya. 2011. Psikoedukasi. Yogyakarta: Penerbit Universitas SanataDharma.
Tilton, A. J. 2004. The Everything Parent's Guide to Children with Autism Know What to Expect Find the Help You Need and Get Through the Day. Massachusetts: Adams MediaAvon.

Wall, K. 2004. Autism and Early Years Practice: A Guide for Early Years Professionals, Teachers, and Parents. London: Paul Chapman Publishing.

Walsh, J. 2010. Psychoeducation in Mental Health - Prectice, Research, and Policy Oxford University Press. Chicago: Lyceum Books, Inc.

Yuwono, J. 2009. Memahami Anak Autistik: Kajian Teoritik dan Empirik. Yogyakarta: Alfabeta. 